\title{
Filstortorias
}

\section{Variações em Torno da Modernidade}

É com satisfação que apresento o dossiê - Variações em torno da modernidade. Os artigos resultam de trabalhos de alunos do curso de graduação em História da Universidade de Brasília, apresentados na disciplina História Moderna. Após o término do curso, em 2012, propus aos alunos que aprofundassem o trabalho, sob minha orientação, como participantes do grupo de pesquisa do CNPQ Tradição e Modernidade. Diante do entusiasmo, passamos a nos reunir regularmente para discussões conjuntas e aprofundamento das pesquisas. Desse trabalho, dois resultaram em monografias de graduação e um em pesquisa desenvolvida no âmbito do Programa de Iniciação Científica. As reuniões propiciaram um contato produtivo entre alunos da graduação e da pós-graduação.

Além da disciplina obrigatória História Moderna, esses alunos cursaram disciplinas optativas da área, por mim oferecidas, e atuaram como monitores. Ao longo de dois anos, o desenvolvimento intelectual dos alunos foi significativo. E para mim, o acompanhamento dos seus trabalhos foi uma experiência gratificante.

Finalmente, diante de amadurecimento dos textos, pensei ser estimulante para os alunos a publicação do resultado das suas pesquisas. Atualmente, alguns desses alunos estão cursando a Pós-Graduação na Universidade de Brasília outros se preparam para o ingresso neste ano.

Os textos apresentados inserem-se na área de História Intelectual e tratam da diversidade de ideias desenvolvidas na Europa moderna. Todos apresentam uma reflexão baseada na historiografia recente sobre os temas tratados, suscitando novas questões e desdobramentos. A preocupação com o contexto histórico de produção dos autores examinados caracteriza uma opção metodológica no âmbito da reflexão sobre ideias.

Os textos de Eduardo Ubaldo Barbosa - O momento Burke. Notas para a história de um Iluminismo contrarevolucionário -, e o de Pedro Henrique Soares Santos - Adam Smith e a sociedade comercial -, dialogam criticamente com determinadas correntes historiográficas e examinam o pensamento dos autores em seus respectivos contextos histórico-intelectual. 
Pedro Eduardo Batista Ferreira da Silva, no artigo James Harrington e a tradição republicana na Inglaterra do século XVII, recupera a tradição republicana inglesa no século XVII.

José Lourenço de Sant'Anna Filho no artigo Inimigos da Luz examina o pensamento do editor do jornal pernambucano A Voz da Religião, padre Tavares da Gama, identificando-o como um representante do pensamento antifilosófico no Brasil oitocentista.

Finalmente, Guilherme Domingues Gonçales, no artigo Iluminismo nos livros didáticos brasileiros, analisa o tema Iluminismo nos livros didáticos brasileiros e sugere o distanciamento dos conteúdos presentes nos livros didáticos em relação às pesquisas acadêmicas.

Dra. Tereza Cristina Kirshner Universidade de Brasília 